\title{
Assessing the roles of temperature, precipitation, and ENSO in dengue re-emergence on the Texas-Mexico border region
}

\author{
Joan M Brunkard, PhD, (I) Enrique Cifuentes, MD, PhD, (2) Stephen J Rothenberg, PhD. ${ }^{(2,3)}$
}

\begin{abstract}
Brunkard JM, Cifuentes E, Rothenberg SJ. Assessing the roles of temperature, precipitation, and ENSO in dengue re-emergence on the Texas-Mexico border region. Salud Publica Mex 2008;50:227-234.
\end{abstract}

\begin{abstract}
Objective. The goal of this study was to assess linkages between microclimate and longer-term ENSO-related weather forcing on the week-to-week changes in dengue prevalence in Matamoros, Tamaulipas, Mexico, over a recent decade of dengue observations. Material and Methods. An auto-regressive model to evaluate the role of climatic factors (seasurface temperature) and weather (maximum temperature, minimum temperature, precipitation) on dengue incidence over the period 1995-2005, was developed by conducting time-series analysis. Results. Dengue incidence increased by $2.6 \%$ (95\% Cl:0.2-5. I) one week after every $1^{\circ} \mathrm{C}$ increase in weekly maximum temperature and increased $1.9 \%(95 \%$ Cl: -0.1-3.9) two weeks after every I cm increase in weekly precipitation. Every $\mathrm{I}^{\circ} \mathrm{C}$ increase in sea surface temperatures (El Niño region 3.4 ) was followed by a $19.4 \%$ (95\% $\mathrm{Cl}$ - -4.7-43.5) increase in dengue incidence (18 weeks later). Conclusions. Climate and weather factors play a small but significant role in dengue transmission in Matamoros, Mexico. This study may provide baseline information for identifying potential longer-term effects of global climate change on dengue expected in the coming decades. To our knowledge, this is the first study to investigate the potential associations between climate and weather events and dengue incidence in this geographical area.
\end{abstract}

Key words: climate; El Niño; dengue; border health; United States; Mexico
Brunkard JM, Cifuentes E, Rothenberg SJ. Evaluación del clima y del ENSO en la reemergencia del dengue en la frontera Texas-México. Salud Publica Mex 2008;50:227-234.

\section{Resumen}

Objetivo. Evaluar los vínculos entre el microclima, las variables relacionadas al fenómeno de El Niño Oscilación del Sur (ENSO) y los cambios en el reporte semanal de casos de dengue en el área de Matamoros, Tamaulipas, México, a lo largo de una década de observaciones. Material y métodos. Se desarrolló un modelo autorregresivo para evaluar la influencia de factores climáticos (temperatura superficial del mar) y tiempo (temperatura máxima, temperatura mínima y precipitación) sobre la incidencia de dengue, a lo largo de II años (1995-2005), empleando análisis de series de tiempo. Resultados. La incidencia de casos de dengue aumentó $2.6 \%$ una semana después de cada $1^{\circ} \mathrm{C}$ de incremento en la temperatura máxima semanal ( $95 \%$ IC: $0.2,5.1)$; observamos también que los casos de dengue aumentaron $1.9 \%$ dos semanas después de cada centímetro de incremento en la precipitación semanal $(95 \%$ IC: $-0.1,3.9)$. Cada I ${ }^{\circ} \mathrm{C}$ de aumento en la temperatura superficial del mar en la región Niño 3.4 fue seguida, 18 semanas después, de un aumento de $19.4 \%$ en la incidencia de casos de dengue (95\% IC: -4.7 , 43.5). Conclusiones. Los factores de clima y tiempo tienen una influencia menor, aunque significativa, sobre la transmisión del dengue en la ciudad fronteriza de Matamoros, México. Este estudio aporta información basal para identificar efectos potenciales de mayor alcance, relacionados con el cambio climático global sobre los casos esperados de dengue en las próximas décadas. Hasta donde sabemos, este es el primer estudio que evalúa las posibles asociaciones entre los eventos climáticos y tiempos y la incidencia de casos de dengue en la frontera de México con Texas.

Palabras clave: clima; Fenómeno de El Niño; dengue; salud fronteriza; Estados Unidos; México

(I) Department of Environmental Studies, University of California. Santa Cruz, California, USA.

(2) Instituto Nacional de Salud Pública. Cuernavaca, México.

(3) CINVESTAV-IPN. Mérida, México.

Received on: January 8, 2007 - Accepted on: December 4, 2007

Address reprint requests to: Enrique Cifuentes. CISP, Salud Ambiental,Instituto Nacional de Salud Pública. Av. Universidad 655,

Col. Santa María Ahuacatitlán. 62508 Cuernavaca, Morelos, México

E-mail: ecifuent@correo.insp.mx 
$\mathrm{A}_{\mathrm{p}}^{\mathrm{n}}$ mong the most significant anticipated health impacts of climate change is an increased incidence of mosquito-borne infectious diseases including dengue and malaria. ${ }^{1-3}$ Dengue is the most serious and prevalent arboviral disease in the world today; two and a half billion people living in the tropics and subtropics are at risk for epidemic transmission. There are an estimated 50-100 million cases of dengue fever each year, ${ }^{4}$ although this is probably an underestimate of the true incidence as many cases likely go unreported because the symptoms of dengue are similar to the flu.

At present, dengue and dengue hemorrhagic fever (DHF), a potentially fatal form of dengue, are largely diseases of the tropics; however, many studies project their expansion with global warming. ${ }^{1,2,5-8}$ Other studies predict limited or no increase in mosquito-borne disease transmission with global warming. 9,10 There is a growing scientific consensus that humans are affecting the global climate system, primarily by the burning of fossil fuels for energy generation, transportation, mechanized agriculture, and other economic activities. The third assessment report by the Intergovernmental Panel on Climate Change (IPCC) projects an increase in global average temperature of between $1.4^{\circ} \mathrm{C}$ and $5.8^{\circ} \mathrm{C}$ by $2100 .{ }^{11}$ Other projected climatic changes include a global average increase in both atmospheric water vapor content and precipitation, and an increase in the frequency and magnitude of extreme weather events. ${ }^{11,12}$

The primary human health consequences associated with climate change are increased mortality related to extreme weather events; an increase in deaths resulting from heat waves; and an increased incidence of vectorborne diseases, particularly malaria, dengue and the viral encephalitides. ${ }^{1,2,13}$ Increased temperatures directly affect the spread of vector-borne diseases in three critical ways: by expanding the geographic range of the vector, by decreasing the extrinsic incubation period (EIP) of the pathogen (the time required for the virus to replicate inside the mosquito and become infectious to another human), and by increasing the contact rate (the biting rate of female mosquitoes). Climate change is projected to expand the latitudinal and altitudinal range of dengue as well as extend its transmission duration in both the tropics and the temperate zones bordering areas where dengue is currently endemic . $1,2,5-7,14,15$

Probably the most critical effect of climate change on dengue transmission will be the reduction in the EIP of the virus. For example, Watts et al. found that the EIP for dengue-2 was 12 days at $30^{\circ} \mathrm{C}$ but only 7 days at $32^{\circ} \mathrm{C}$ to $35^{\circ} \mathrm{C} .{ }^{16} \mathrm{~A}$ related study showed that a five-day decrease in the EIP for dengue translated to a potential three-fold increase in dengue transmission. ${ }^{17}$ A shorter incubation time for the disease-causing agent is a critical factor in epidemic potential because it greatly increases the likelihood that a mosquito will live long enough to become infectious and bite a susceptible human, thus continuing the dengue transmission cycle.

Elevated temperatures increase the contact or biting rate of mosquitoes in several ways. First, warmer temperatures reduce the larval size of Aedes mosquitoes, resulting in smaller adults that must feed more often to develop their egg batch. ${ }^{18}$ Additionally, adult mosquitoes digest blood more quickly at higher temperatures and therefore need to obtain bloodmeals more frequently. ${ }^{19}$

Precipitation variability and more extreme weather events may also increase mosquito-borne disease incidence. ${ }^{3}$ Areas that receive increased precipitation or experience an increase in the frequency or magnitude of extreme weather events will likely experience an expansion of vector breeding sites and larval habitat. ${ }^{20} \mathrm{El}$ Niño events represent the best analog for the impacts of increased frequency of extreme weather events. A number of studies have documented an increased incidence of malaria associated with El Niño events, ${ }^{20-25}$ but evidence for dengue-ENSO (El Niño Southern Oscillation) associations is equivocal. ${ }^{26}$ Extreme weather events are also likely to facilitate the spread of dengue by disrupting water supply, sewerage and sanitation services. The interruption of basic public health and safety measures that frequently follow such events provides an ideal environment for the vector while leaving humans vulnerable to an increased rate of mosquito biting. ${ }^{27,28}$

Regional studies are needed to explore the potential links between climatic variables and disease emergence. ${ }^{3}$ While several studies have looked at links between climatic variables, ENSO, and dengue, ${ }^{29-31}$ very few have examined these associations in Latin America. To our knowledge, this is the first study to investigate the potential associations between climate and weather events and dengue incidence on the Texas-Mexico border.

\section{Study objectives}

The goal of this study was to assess linkages between microclimate and longer-term ENSO-related weather forcing on the week-to-week changes in dengue prevalence in a restricted geographic area over a single recent decade of dengue observations. This study does not address the issue of climate change effect on dengue incidence, per se. Such studies here and in many other areas will provide baseline information for identifying potential longer-term effects of global climate change on dengue expected in the coming decades. 


\section{Material and Methods}

\section{Data}

An auto-regressive model was developed to evaluate the role of climatic factors on dengue incidence over an eleven year period (1995-2005). We compiled daily data for maximum temperature, minimum temperature, and precipitation from the most reliable weather station in the region, the Brownsville South Padre, Texas airport (WMO\# 722500; latitude/longitude: 25(deg) 54' 28.17" N, 97 (deg) 25' 29.61" W ; elevation +000 m.a.s.1.). Climate data for the eleven-year series were obtained from the National Climatic Data Center (NCDC). * From 4017 daily observations at the Brownsville airport weather station, there were a total of 129 missing values in the NCDC database (14 for maximum temperature, 15 for minimum temperature, and 100 for precipitation). The missing values were obtained from the same weather station using a different database, the National Weather Service database. ${ }^{\ddagger}$ Weekly sea surface temperatures were obtained from the National Oceanic and Atmospheric Administration (NOAA) for Niño 3.4 region (120-170W, $5 \mathrm{~S}-5 \mathrm{~N})^{\S}$ and used as an ENSO indicator.

For dengue data, we used weekly incidence data from the city of Matamoros, Tamaulipas, Mexico ${ }^{\#}$ because it is the most reliable and thorough dataset in the region. Daily data were transformed into maximum and minimum weekly temperatures and total accumulated weekly precipitation amounts to correspond with weekly epidemiological dengue reporting (Sunday through Saturday), a reporting system standardized across the western hemisphere by the Pan American Health Organization. All dengue case reports (table I) were serologically confirmed at the state lab (Laboratorio Estatal de Salud Pública) in Ciudad Victoria, Tamaulipas, Mexico.

\section{Statistical methods}

To measure the effect of temperature, precipitation, and ENSO cycle on dengue incidence using standard regression procedures, serial correlation in the dengue time series must first be removed. We added one case to each weekly dengue count and natural log-transformed

\footnotetext{
* Available from: http:/ / climvis.ncdc.noaa.gov/cgi-bin/gsod_xmgr

‡ Available from: http://www.srh.noaa.gov/bro/

$\S$ Available from: http://www.cpc.noaa.gov/data/indices/wksst.for

* Secretaría de Salud, Tamaulipas, Mexico, unpublished data.
}

the series to stabilize variance. We then determined lack of temporal trend with the Dickey-Fuller unit root test. $^{32}$ Serial correlation was diagnosed with autocorrelation and partial autocorrelation functions, and then empirically reduced by successive additions of lagged autoregressive terms to the series. The process was terminated when the portmanteau test ${ }^{33}$ and Bartlett's white noise test ${ }^{34}$ indicated no significant autocorrelation among residuals. Using cross-correlation functions, we tested the residuals of the autoregressive series with each weather variable at biologically-plausible time lags to determine optimal time lags maximizing cross-correlations.The autoregressive terms and lagged weather variables were entered into an ARMAX model to calculate variable coefficients and standard errors, and generate model residuals and predictions. ARMAX models are linear regressions $(X)$ with the error term specified with autoregressive (AR) and / or moving average (MA) terms. We used only autoregressive terms without moving average terms. Diagnostics indicated residual heteroscedasticity and the ARMAX model was rerun using standard error estimation that was robust to departure from homoscedasticity. Residuals were symmetrically distributed about a mean of zero.

We tested two models with identical covariate and ARMA structures [AR(2) MA(0)], one using the full 11-year data set, the other using only the first 10 years of data for estimation. We compared predictions with observations of the 11th year of data using both models as a model validation procedure. Data management and statistical procedures were performed with Stata 9.1 (StataCorp, College Station, TX).

\section{Results}

From 1995-2005, there were 2865 reported cases of dengue and 43 reported cases of dengue hemorrhagic fever in Matamoros, Tamaulipas, Mexico. ${ }^{*}$ The highest dengue incidence occurred in 1997, followed by 2005 (table I).

Time series were plotted for all climatic variables and dengue incidence to observe their behavior and patterns of seasonal and inter-annual variability (figures 1-4). Using the full eleven-year dataset (1995-2005), our ARMAX model (table II) showed that dengue incidence increased by $2.6 \%$ (95\% CI: 0.2-5.1) one week after every $1^{\circ} \mathrm{C}$ increase in weekly maximum temperature and increased 1.9\% (95\% CI: -0.1-3.9) two weeks after

* Secretaría de Salud, Tamaulipas, Mexico, unpublished data. 
Table I

Reported dengue AND DHF INCIDENCE in Matamoros (1995-2005)

\begin{tabular}{lrrr} 
Year & Dengue & DHF & Total dengue \\
1995 & 319 & 0 & 319 \\
\hline 1996 & 373 & 19 & 392 \\
\hline 1997 & 815 & 10 & 825 \\
\hline 1998 & 178 & 5 & 183 \\
\hline 1999 & 406 & 0 & 406 \\
\hline 2000 & 161 & 2 & 163 \\
\hline 2001 & 8 & 0 & 8 \\
\hline 2002 & 100 & 4 & 104 \\
\hline 2003 & 3 & 2 & 5 \\
\hline 2004 & 28 & 1 & 29 \\
\hline 2005 & 474 & $*$ & $474^{\ddagger}$
\end{tabular}

* Data are not available for number of hemorrhagic cases in 2005

‡ Incidence data for 2005 represents only those cases that were laboratory-confirmed.Several thousand additional probable cases were reported, including several hundred cases of dengue hemorrhagic fever, but blood samples were not collected (Secretaría de Salud, Tamaulipas, Mexico, unpublished data)

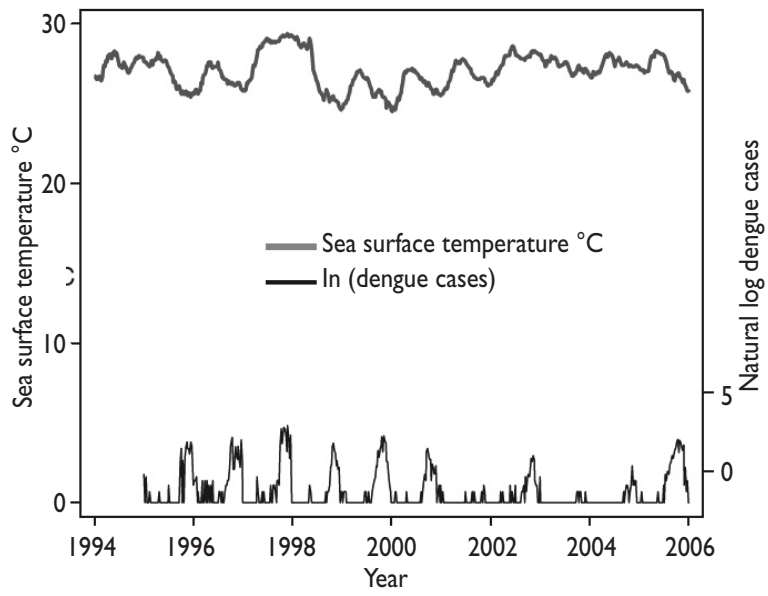

Figure I. Time series of dengue AND SEA surface temPERATURE $\left({ }^{\circ} \mathrm{C}\right)$

every $1 \mathrm{~cm}$ increase in weekly precipitation. Every $1^{\circ} \mathrm{C}$ increase in sea surface temperatures in the equatorial Pacific, Nino region 3.4 was associated with a $19.4 \%$ (95\% CI: -4.7-43.5) increase in dengue incidence 18 weeks later. Minimum temperature was not signifi-

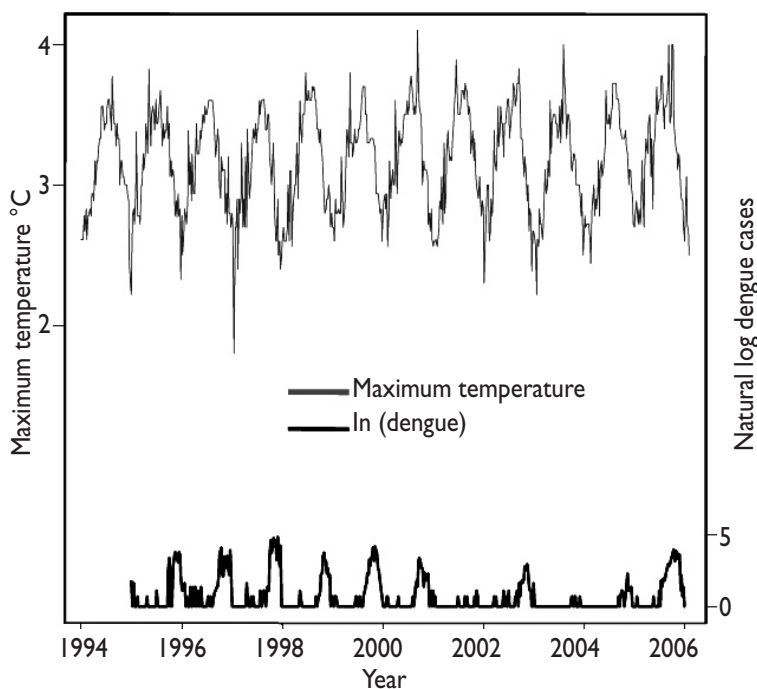

Figure 2:TIME SERIES OF DENGUE AND MAXIMUM TEMPERATURE $\left({ }^{\circ} \mathrm{C}\right)$

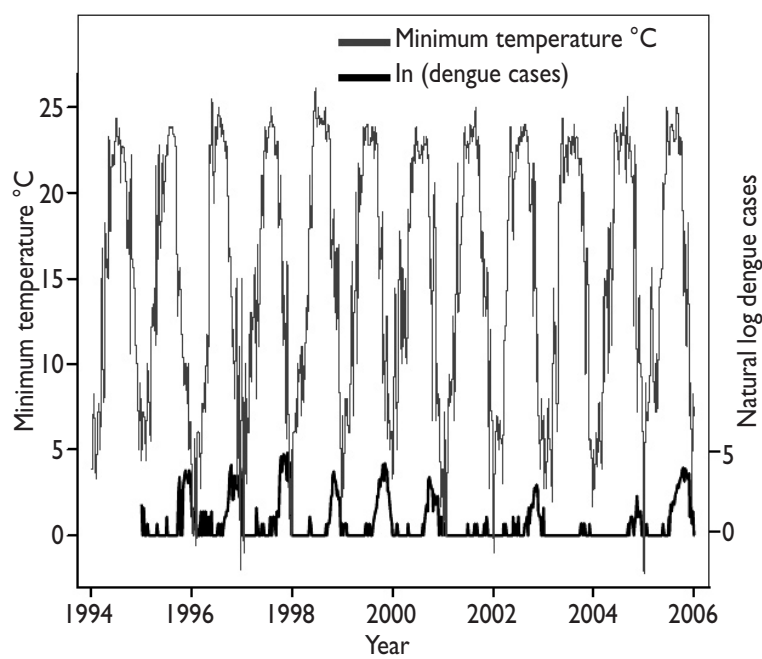

Figure 3:TIME SERIES OF DENGUE AND MiNIMUM TEMPERATURE $\left({ }^{\circ} \mathrm{C}\right)$

cantly associated with dengue incidence $(p=0.26)$ and was dropped from the model.

We validated the basic model by re-estimation using data from the first 10 years, 1995 through 2004 (table III and figure 5), to predict dengue incidence 


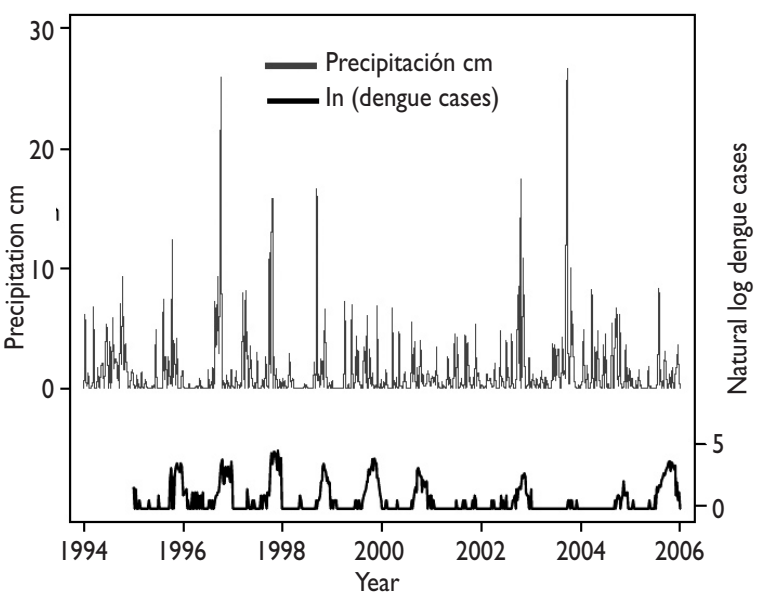

* Data are in epidemiological weeks, Sunday through Saturday, with each year beginning at week I

Figure 4. TIME SERIES OF DeNGUe AND PRECIPITATION (CM)

Table II

ARMAX MOdel FOR TIME SERIES 1995-2005

\begin{tabular}{|c|c|c|c|c|}
\hline Ln(dengue) & Coef. & z-statistic & p-value & $95 \%$ Conf. Interva \\
\hline Max temp ${ }^{\circ} \mathrm{C} L I^{*}$ & .026 & 2.11 & 0.035 & $.002, .051$ \\
\hline Precip $(\mathrm{cm}$.$) L2*$ & .019 & 1.88 & 0.060 & $-.001, .039$ \\
\hline Sea surface temp LI8* & .194 & 1.58 & 0.114 & $-.047, \quad .435$ \\
\hline $\operatorname{AR}(L I)^{*}$ & .532 & 7.28 & 0.000 & $.389, .675$ \\
\hline$\overline{\mathrm{AR}(\mathrm{L} 2)^{*}}$ & .359 & 5.04 & 0.000 & $.219, .498$ \\
\hline
\end{tabular}

in the eleventh year, 2005 (figure 6). Coefficients did not change significantly between the model estimated with all eleven years and the ten-year model. The predictions in figures 5 and 6 used both the endogenous (the autoregressive variables) and the exogenous (the climate variables) components of the model. Finally we plotted the predictions of the model based on the entire series, 1995-2005 (figure 7), and compared them with the model predictions from the ten-year series, 1995-2004 (figure 6).

There is very little difference between the within (2004) and out-of-series (2005) model predictions as most
Table III

ARMAX MODEL FOR TIME SERIES I995-2004

\begin{tabular}{lcccc} 
Ln(dengue) & Coef. & $z$-statistic & $p$-value & $95 \%$ Conf. Interval \\
Max temp ${ }^{\circ} \mathrm{C} \mathrm{LI} *$ & .025 & 1.83 & 0.068 & $-.002, .052$ \\
\hline Precip (cm.) L2* & .020 & 1.93 & 0.053 & $-.000, .041$ \\
\hline Sea surface temp LI8* & .141 & 1.14 & 0.255 & $-.101, .382$ \\
& & & & \\
$\operatorname{AR}(I)^{*}$ & .545 & 6.91 & 0.000 & $.390, .700$ \\
\hline $\operatorname{AR}(2)^{*}$ & .335 & 4.35 & 0.000 & $.184, .486$
\end{tabular}

Wald Chi square $(5)=748.2, p<0.0001, n=522$

$L^{*}=$ number of weeks lag

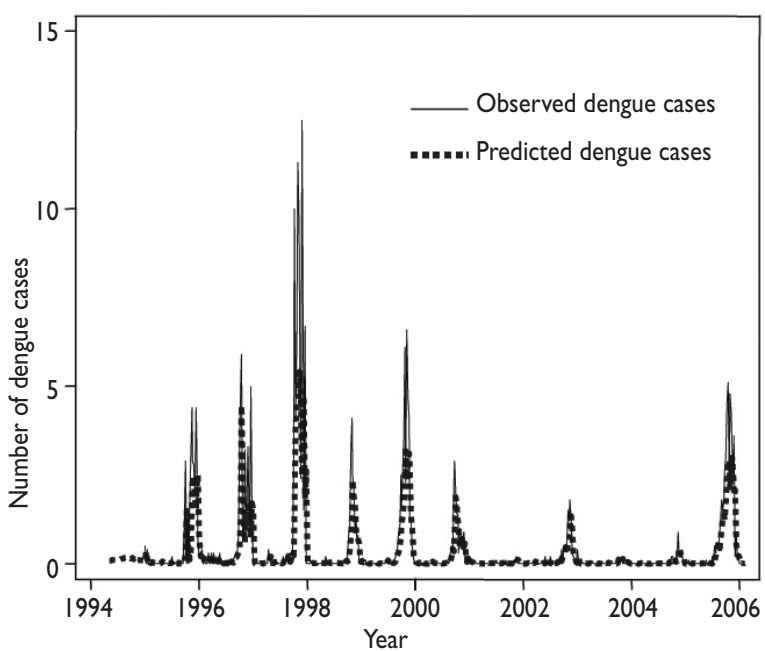

Figure 5. Estimation model (1995-2004)

of the predictive power comes from the autoregressive terms, whose coefficients are not significantly different in the two models. Despite the strong influence of the autoregressive components in the model, adding the three climate variables resulted in significant improvement in model fit (Chi-squared(3) $=11.12, p=0.011$ ) using the full 11-year model.

\section{Discussion}

Based on this time series analysis, weather and climatic factors together play a significant but small role in dengue transmission in the border city of Matamoros, Mexico. The predictive ability of our models (table II 


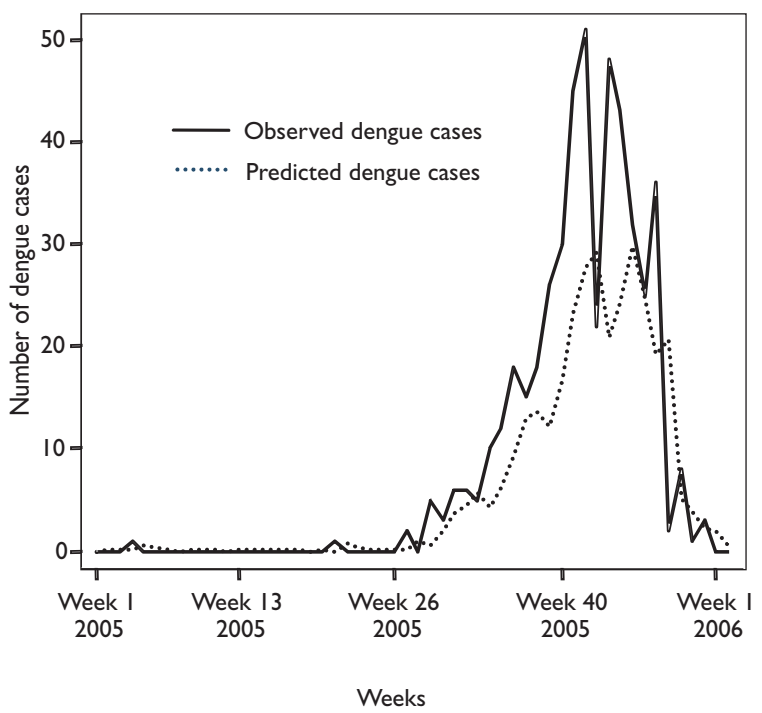

Figure 6. OUt OF SERIES (1995-2004) MODEL PREDICTION FOR 2005

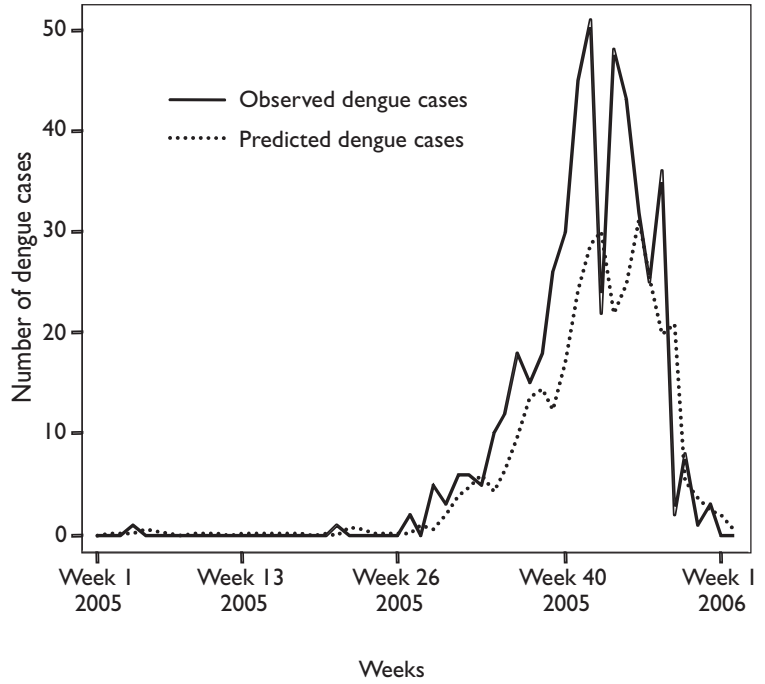

Figure 7.Within SERIES (1995-2005) MOdel PREDiction FOR 2005

and III) is largely due to unmeasured endogenous autoregressive factors in the dengue series, which we can not further specify without more information on the full range of factors influencing dengue transmission in this region. Time series modeling is inherently data-driven. Though the autoregressive order determinations and the specific lagged independent variables were selected to optimally condition the series within biological and physical bounds, it is likely that the lags for the variables described here are place-specific and will vary somewhat in locales with other weather conditions and climatic patterns.

We can conclude, however, that endogenous predictive power in the dengue case series does not extend beyond two weeks in Matamoros. Year-to-year variability in dengue seroprevalence is likely a function of herd immunity and the presence of specific dengue serotypes and strains, ${ }^{35}$ not measured here. Other studies investigating the relative role of climatic factors on mosquito-borne disease incidence have similarly found that endogenous factors dominate. ${ }^{36,37}$

Our objectives were to determine if the ENSO climate indicator and weather variables played some role in weekly dengue cases. The autoregressive terms in our models were only used to condition the time series of dengue cases so that we could apply the techniques of ordinary least squares regression to test the effect of the climate indicator and weather variables in weekly dengue cases. The addition of maximum temperature, precipitation, and sea surface temperature significantly improved model fit to the data $(p=0.011)$.

Our findings with respect to temperature, precipitation and sea surface temperature are in general agreement with the findings of Hurtado-Díaz et al. ${ }^{38}$ who constructed a similar model to study the climatedengue relationship in the state of Veracruz, Mexico. SSTs were highest in 1997, coinciding with the highest year of reported dengue incidence in Matamoros and in Veracruz, and Hurtado-Díaz et al. ${ }^{38}$ detected a small influence of precipitation and minimum temperature. In the Texas-Mexico border region, maximum temperature is more influential than minimum temperature for dengue transmission because its fluctuations cross nonlinear thresholds for key biological processes, such as the dramatic reduction in the extrinsic incubation period of the virus at $32^{\circ} \mathrm{C} .{ }^{16} \mathrm{As}$ in our model, other studies have found that predictive models under-estimate actual cases of mosquito-borne disease, especially in high incidence years. ${ }^{39}$

Under-reporting of disease incidence is a serious and widespread limitation to modeling climate-disease relationships. Our response variable is almost certainly an underestimate of regional dengue incidence. Even accounting for improved reporting on the Mexican side of the border, we are confident that dengue cases are higher than official incidence reports. For example, a serosurvey in 2004 found that $7.7 \%$ of Matamoros 
residents had experienced a recent (within 2004) dengue infection.$^{40}$ But official statistics place 2004 as one of the lowest years of dengue incidence in the series (table I). A dengue serosurvey in El Salvador found similar pervasive under-reporting. ${ }^{41}$ Lopez-Correa et al. (1979) calculated that there were at least 46 undiagnosed dengue cases for every reported case from their survey in Puerto Rico. ${ }^{42}$ The times series of dengue and precipitation co-variance (figure 4) seems to suggest that 2004 should have been a high incidence year, as it was, but cases were not registered and therefore were not factored into our model. We suspect that the observed influence of precipitation on dengue incidence in our models would have been much stronger if dengue incidence had not been under-reported.

Current evidence suggests that non-climatic factors play the biggest role in mosquito-borne disease incidence. ${ }^{43,44}$ However, completely discounting the role of climate in disease emergence is premature ${ }^{45}$ we need better models and more reliable data. In this region of the US-Mexico border, residents and public health officials intuitively know that climate plays a role in dengue transmission. For example, when one resident was asked if she knew how dengue was transmitted, her response was: "I don't know. The mosquito, I think. All of a sudden the rain comes and the dengue is here." Another survey participant commented, "It's warm all the time here, and the mosquitoes don't die off here." And when asked how often the city sprayed for mosquitoes, one resident observed: "during the summer, yes-but sometimes we have mosquitoes during the winter too." Local public health officials likewise commented that with the onset of the rainy season and high temperatures, they were likely to see dengue cases. ${ }^{*}$

Development of active surveillance for mosquitoborne diseases and Early Warning Systems (EWS) are key public health goals ${ }^{46}$ but integrating climate data into predictive frameworks for infectious diseases has not yet been achieved. ${ }^{3}$ However, advances in this area are being made. A recent retrospective analysis of malaria prevalence in Botswana, Africa demonstrated that multiple models using ENSO indicators provide a five-month lead time on disease prediction whereas data on precipitation alone only gives a one-month lead, ${ }^{47}$ lag times similar to those described in this study. Such findings show promise, but institutional support for integration of climate data into EWS is not yet present in this region.

\footnotetext{
* Robles-López JL, personal communication.
}

\section{References}

I. Shope R. Global climate change and infectious diseases. Environ Health Perspect 1991;96:171-174.

2. McCarthy JJ, Canziani OF, Leary NA, Dokken DJ, White KS. Climate Change 200I: Impacts, Adaptation and Vulnerability (Contribution of Working Group II to the Third Assessment Report of the Intergovernmental Panel on Climate Change) Geneva, Switzerland: IPCC, 2001.

3. National Research Council. Under the weather: climate, ecosystems, and infectious disease. Washington, DC: National Academy Press; $200 \mathrm{I}$. 4.World Health Organization. 2002. Dengue and dengue haemorrhagic fever Fact Sheet No. I 17.Available from: http://www.who.int/mediacentre/ factsheets/fs I I7/en/index.html

5. Jetten TH, Focks DA. Potential changes in the distribution of dengue transmission under climate warming. Am J Trop Med Hyg 1997;57:285-297. 6. Martens WJM, Jetten TH, Focks DA. Sensitivity of malaria, schistosomiasis and dengue to global warming. Climatic Change 1997;35: 145-156.

7. Patz JA, Martens WJ, Focks DA, Jetten TH. Dengue fever epidemic potential as projected by general circulation models of global climate change. Environ Health Perspect 1998; 106:147-153.

8. Hales S, de Wet N, Maindonald J,Woodward A. Potential effect of population and climate changes on global distribution of dengue fever: an empirical model. Lancet 2002;360:830-834.

9. Rogers DJ, Randolph SE. The global spread of malaria in a future, warmer world. Science 2000;289:1763-1766.

10. Reiter P. Climate change and mosquito-borne disease. Environ Health Perspect 200I;109:14I-16I.

II. Houghton JT, Ding Y, Griggs DJ, Noguer M, Linden PJvd, Xiaosu D. Climate Change 200I:The Scientific Basis (Contribution of Working Group I to the Third Assessment Report of the Intergovernmental Panel on Climate Change). Geneva, Switzerland: IPCC, 200 I.

I2. Easterling DR, Meehl GA, Parmesan C, Changnon SA, Karl TR, Mearns LO. Climate extremes: observations, modeling, and impacts. Science 2000;289:2068-2074.

13. Houghton JT. Global warming: the complete briefing. 2nd ed. Cambridge, New York: Cambridge University Press, 1997.

14. Patz JA, Epstein PR, Burke TA, Balbus JM. Global climate change and emerging infectious diseases. JAMA 1996;275:217-223.

15. Epstein PR, Diaz HF, Elias S, Grabherr G, Graham NE, Martens WJM, et al. Biological and physical signs of climate change: Focus on mosquitoborne diseases. Bull Am Meteorol Soc 1998;79(3):409-4I7.

16. Watts DM, Burke DS, Harrison BA, Whitmire RE, Nisalak A. Effect of temperature on the vector efficiency of Aedes aegypti for dengue 2 virus. Am JTrop Med Hyg 1987;36: 143-152.

17. Koopman JS, Prevots DR, Vaca Marin MA, Gomez Dantes H, Zarate Aquino ML, Longini IM, Jr, et al. Determinants and predictors of dengue infection in Mexico. Am J Epidemiol 1991; 133: I 168-1 178.

18. Rueda LM, Patel KJ,Axtell RC, Stinner RE. Temperature-dependent development and survival rates of Culex quinquefasciatus and Aedes aegypti (Diptera: Culicidae). J Med Entomol 1990;27:892-898.

19. Gillies MT.The duration of the gonotrophic cycle in Anopheles gambiae and Anopheles funestus, with a note on the efficiency of hand catching. East Afr Med J 1953;30: I29-1 35.

20. Githeko AK, Lindsay SW, Confalonieri UE, Patz JA. Climate change and vector-borne diseases: a regional analysis. Bull World Health Organ 2000;78: II36-II47.

21. Kovats RS. El Nino and human health. Bull World Health Organ 2000;78: II27-II35.

22. Bouma MJ, van der Kaay HJ.The El Nino Southern Oscillation and the historic malaria epidemics on the Indian subcontinent and Sri Lanka: 
an early warning system for future epidemics? Trop Med Int Health 1996; |:86-96.

23. Bouma MJ, Poveda G, Rojas W, Chavasse D, Quinones M, Cox J, et al. Predicting high-risk years for malaria in Colombia using parameters of El Nino Southern Oscillation. Trop Med Int Health 1997; 2: I I22-I I 27. 24. Bouma MJ, Dye C. Cycles of malaria associated with El Nino in Venezuela. JAMA 1997; 278:1772-1774.

25. Poveda G, Rojas W, Quinones ML, Velez ID, Mantilla RI, Ruiz D, et al. Coupling between annual and ENSO timescales in the malaria-climate association in Colombia. Environ Health Perspect 2001;109:489-493. 26. Kovats RS, Bouma MJ, Hajat S, Worrall E, Haines A. El Nino and health. Lancet 2003;362: I48I-I489.

27. Bouma MJ, Kovats RS, Goubet SA, Cox JS, Haines A. Global assessment of El Nino's disaster burden. Lancet 1997;350:1435- I438.

28. Noji EK. The public health consequences of disasters. New York: Oxford University Press, 1997.

29. Hales S, Weinstein P, Souares Y,Woodward A. El Nino and the dynamics of vectorborne disease transmission. Environ Health Perspect 1999;107:99-102.

30. Corwin AL, Larasati RP, Bangs MJ,Wuryadi S, Arjoso S, Sukri N, et al. Epidemic dengue transmission in southern Sumatra, Indonesia. Trans R Soc Trop Med Hyg 200I;95:257-265.

31. Gagnon AS, Bush ABG, Smoyer-Tomic KE. Dengue epidemics and the El Nino Southern Oscillation. Climate Research 2000;19:35-43. 32. Dickey DA, Fuller WA. Distribution of the Estimators for Autoregressive Time-Series with a Unit Root. Journal of the American Statistical Association 1979;74:427-431.

33. Ljung GM, Box GEP. Measure of Lack of Fit in Time-Series Models. Biometrika 1978;65:297-303.

34. Bartlett MS.An introduction to stochastic processes, with special reference to methods and applications. Cambridge [Eng.]: University Press, 1955.

35. Halstead SB. Pathogenesis of dengue: challenges to molecular biology. Science 1988;239:476-48I.

36. Hay SI, Myers MF, Burke DS, Vaughn DW, Endy T,Ananda N, et al. Etiology of interepidemic periods of mosquito-borne disease. Proc Natl Acad Sci USA 2000;97:9335-9339.
37. Thammapalo S, Chongsuwiwatwong V, McNeil D, Geater A. The climatic factors influencing the occurrence of dengue hemorrhagic fever in Thailand. Southeast Asian J Trop Med Public Health 2005;36: 191-196. 38. Hurtado-Díaz M, Riojas-Rodríguez H, Rothemberg SJ, Gómez-Dantés O, Cifuentes E. Short Communication: Impact of Climate Variabiity on the Incidence of Dengue in Mexico. Trop Med Int Health 2007; I2:I327-I337. 39. Teklehaimanot HD, Schwartz J, Teklehaimanot A, Lipsitch M. Weatherbased prediction of Plasmodium falciparum malaria in epidemic-prone regions of Ethiopia II. Weather-based prediction systems perform comparably to early detection systems in identifying times for interventions. Malar J 2004;3:44.

40. Brunkard J, Robles J, Ramirez J, Cifuentes E, Rothenberg S, Hunsperger E, et al. Dengue Fever Seroprevalence and Risk Factors, Texas-Mexico Border, 2004. Emerging Infectious Diseases 2007; 13(10): 1477- I 483. 4I. Hayes JM, Garcia-Rivera E, Flores-Reyna R, Suarez-Rangel G, Rodriguez-Mata T, Coto-Portillo R, et al. Risk factors for infection during a severe dengue outbreak in El Salvador in 2000.Am J Trop Med Hyg 2003;69:629-633.

42. Lopez-Correa RH, Moore CG, Sather GE, Morens DM, Chiriboga J, Banegura F, et al.The 1977 dengue epidemic in Puerto Rico: Epidemiologic and clinical observations. Dengue in the Caribbean, 1977, Proceedings of a Workshop, 8-II May 1978, Pan-American Health Organization; 1979; Washington, DC; Pan-American Health Organization, 1979.

43. Gubler DJ, Kuno G. Dengue and dengue hemorrhagic fever. Wallingford, Oxon, UK. New York: CAB International, 1997. 44. Reiter P, Lathrop S, Bunning M, Biggerstaff B, Singer D, Tiwari T, et al. Texas lifestyle limits transmission of dengue virus. Emerg Infect $D$ is 2003;9:86-89

45. Bouma MJ. Methodological problems and amendments to demonstrate effects of temperature on the epidemiology of malaria. A new perspective on the highland epidemics in Madagascar, 1972-89. Trans R Soc Trop Med Hyg 2003;97:133-139.

46. Gubler DJ. Surveillance for dengue and dengue hemorrhagic fever. Bull Pan Am Health Organ 1989;23:397-404.

47. Thomson MC, Doblas-Reyes FJ, Mason S], Hagedorn R, Connor SJ, Phindela T, et al. Malaria early warnings based on seasonal climate forecasts from multi-model ensembles. Nature 2006;439:576-579. 